NASA Technical Memorandum 89856

AIAA-87-1098

\title{
The NASA Electric Propulsion Program
}

David C. Byers

Lewis Research Center

Cleveland, Ohio

and

Robert A. Wasel

NASA Headquarters

Washington, D.C.

(NASA-TM-89856) THE NASA ELECTEIC
EROPULSICN PECGE

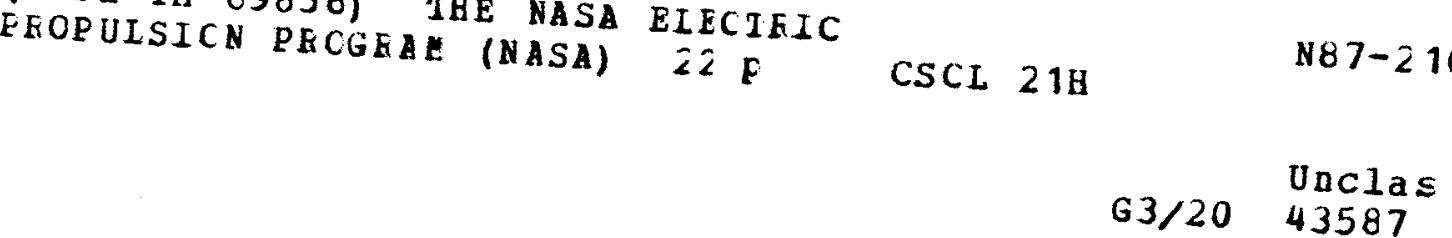

Prepared for the

19th International Electric Propulsion Conference

cosponsored by the AIAA, DGLR, and JSASS

Colorado Springs, Colorado, May 11-13, 1987 


\author{
David C. Byers* \\ National Aeronautics and Space Administration \\ Lewis Research Center \\ Cleveland, Ohio 44135 \\ and \\ Robert A. Wase 1* \\ NASA Headquarters \\ Office of Aeronautics and Space Technology \\ Washington, D.C. 20546
}

\begin{abstract}
The NASA OAST Propulsion, Power, and Energy Oivision supports electric propulsion for a broad class of missions. Concepts with potential to significantly benefit or enable space exploration and exploitation are identified and advanced toward applications in the near to far term. This paper summarizes recent program progress in mission/system analyses and in electrothermal, ion, and electromagnetic technologies.

\section{Introduction}

Prospects now appear high for broad acceptance and application of electric propulsion systems. Low power, pulsed plasma thrusters are in use for very precise orbit control ${ }^{1}$ on Navy NOVA spacecraft and $500-W$ class augmented hydrazine resistojets are operational on many geosynchronous communication satellites.2 These first applications have provided users with considerable information on the integration requirements and potentials of electric propulsion and are important milestones toward its full exploitation.
\end{abstract}

Multipropellant resistojets 3 have been selected for the Initial operating Capability (IOC) Space Station 4 as their use nearly eliminates the necessity for both launch of drag make-up propellants and, importantly, the return of waste fluids from Station subsystems. The use of high power, primary electric propulsion was strongly endorsed by the report of the National Commission on Space. 5 Applications cited therein included both Earthorbit and planetary cargo transfer vehicles. Large solar 6 and nuclear space power systems, whose lack of avallability has lang prevented the realization of primary electric propulsion, are now under development for space demonstration and/or use in the 1990's. In addition to these developments, recent 8,9 and planned 10,11 space tests give further evidence of the interest, and will, of various agencies to develop electric propulsion.

The NASA electric propulsion program supports both system and mission analyses and research and technology efforts on several propuision concepts. Studies are aimed at defining the requirements for, and impacts of, advanced propulsion for a broad range of applications from low power auxiliary functions to large cargo transfer vehicles. The requirements of the many applications and missions are often very disparate. The program, therefore, addresses a range of technologies in the areas of electrothermal, ion, and electromagnetic propulsion.

* Member AIAA.
The following highlights selected accomplishments in the analysis and technology areas to fllustrate program content and direction.

\section{Mission and System Analyses}

Recent studies have analyzed electric propul. sion systems and applications ranging from $1 \mathrm{~kW}$ class concepts for stationkeeping to severalhundred-megawatt Nuclear Electric Propulsion Systems (NEPS) for Earth-orbit and planetary missions. For completeness, some studies sponsored by agencies other than NASA will be presented.

Schreib, 12 in a review of the INTELSAT sponsored xenon ion propulsion program, evaluated the integration issues and cost benefits of ion systems on three-axis and spin-stabilized communication satellites. Table 1 , from Ref. 12, shows the calculated net mass and cost benefits for such spacecraft, where direct solar array power was used, if required, to supplement the $2.0 \mathrm{~kW}-\mathrm{hr}$ energy supplled by batterles used for equinox operations. The net benefits are very large and approach the cost of typical communication satellites in some cases.

As previously noted, multipropellant resistojets were baselined for the IOC Space Station. Interest in these systems arose 4 from their strong synergism with other Station subsystems, such as the Environmental Control and Life Support System (ECLSS), and other advantages accruing from low thrust levels and the use of gaseous, benign propellants. Large life cycle cost savings are projected 13,14 for space station by use of resistojet systems which are described in detali in Ref. 15 . In the long run, selection of the multipropellant resistojets may well represent an important step in the development of integrated on-board propulsion systems which can provide large potential benefits to launch, orbit transfer, and space systems.

Palaszewski16 systematically evaluated the use of various electric propulsion concepts for a variety of functions on polar and co-orbiting free flyer spacecraft. Table 2 shows the propellant masses 16 required for servicing of several co-orbiting space systems. The mission velocity increments were extremely sensitive to the altitudes and servicing intervals chosen and values of those were selected to minimize the propulsion requirements. The very large potential benefits of electric propulsion for servicing co-orbiting free flyers is clearly shown in Table 2 as, dependent on the technology assumed, up to an order of magnitude reduction in propellant, relative to the baseline hydrazine system, can be realized. As discussed in Ref. 16, low acceleration requirements exist for 
several free flyer missions. In those cases, low thrust electric propulsion of fers advantages beyond the propulsion mass reductions discussed above.

Perhaps stimulated by the SP-100 program, 7 NASA 17,18 and Air Force 19 sponsored efforts were conducted to evaluate NEPS for several missions. Serce 1 and Krauthamer 17 conducted a detailed study of NEPS for LEO-GEO, Lunar Base, and Neptune Orbiter missions. In that study the impacts of power level and electric propulsion technology (MPO and ion) on mission performance were obtained and compared with advanced chemical propulsion. Figures $1(a)$ and (b) show the transportation mass per mission and average trip times, 17 assuming MPD propulsion systems, as a function of NEPS power level for LEO-GEO and Lunar Base missions, respectively. Below 1.0 MWe, the power and ion propulsion system specific mass was assumed to be $25 \mathrm{kG} / \mathrm{kW}$. Above $1.0 \mathrm{MWe}$, the power and MPD propulsion system specific mass was assumed to be $6 \mathrm{kG} / \mathrm{kW}$. The performance of an advanced (485 sec specific impulse, space based, aerobraked) chemical system was also evaluated and the transportation mass per mission was about 30 and 75 metric tons per mission for the LEO-GEO and Lunar Base missions, respectively. The potential saving in transportation mass provided by NEPS, relative to advanced chemical systems, ranged for both missions from a factor of two, for high power, to a factor of $s i x$, for the lowest NEPS power level studied. The high power NEPS systems did, however, enable significant reduction in trip times which could be of great importance in overall mission designs and costs. Figure 2 shows the Neptune Orbiter mission trip time 17 for the two power regimes with ion and MPD systems. For comparison, single Space Shuttle missions using hydrogen/oxygen propulsion systems have been shown 20 to require from 15 to $20 \mathrm{yr}$ for this mission. It can be seen that NEPS can save from about 3 to $10 \mathrm{yr}$ trip time, dependent on power level, and that the fon system trip times are about 1.5 yr shorter than those with MPD systems. Reference 17 also evaluated very high power NEPS for manned missions to several planets. Trip times for 200 MWe NEPS, minimized by selection of appropriate specific impulses, of about six months, two years, and seven years were obtained for round trips to Mars, Jupiter, and Neptune, respectively.

Reference 18 presented parametric estimates of the dry masses of resistojet, arcjet, and ion propulsion systems and the mission performance (velocity increments and thrusting times) that could be obtained with the assumption of a single Shuttle launch of an SP-100 power system. Figure 3 shows the mass breakouts, for an assumed $300 \mathrm{kWe}$ SP-J00 system, for the three electric propulsion systems. In all cases, the propulsion system dry mass was a small fraction of the Shuttle Orbiter payload. The xenon ion system dry mass was heavier than that of either the resistojet or arcjet system but, due to higher specific impulse, could deliver significantly more velocity increments and thrusting times (Figs. 4(a) and (b)).

As a final example of misston analyses, an Air Force study 19 evaluated a reusable NEPS for the delivery of a galaxy of 28 Global positioning System (GPS) satellites, to a $20187 \mathrm{kM}$ orbit. Table 3 shows estimated overall galaxy deployment costs for several propulsion systems. The cost savings estimated in Ref. 19 are very great, in large part due to the reusability of the NEPS, which much more than offset the higher initial cost of the NEPS with respect to the other, chemical, systems.

In general, the studies cited have affirmed the great leverage that can be provided by electric propulsion systems for a very broad class of missions. Benefits can be realized in a number of ways including major reductions of: (1) mission life cycle costs, (2) propellant masses, and (3) orbit transfer times for planetary missions, and/or large extensions of on-orbit lifetimes.

\section{Electrothermal}

Efforts in electrothermal propulsion include multipropellant resistojets for Space Station, high performance resistojets for spacecraft, low power $D C$ arcjets, and research on high power thruster concepts.

\section{Multipropellant Resistojets}

Presently, multipropellant resistojets are planned for drag make-up propulsion on the IOC Space Station ( $F i g .5$ ). A number of technical issues were addressed in order to provide the confidence required for that selection. Grain stabilized platinum was selected ${ }^{3}$ for the heat exchanger and nozzle and many tests were performed 21,22 in material test cells to verify the compatibility of the stabllized platinum with candidate propellants. Figure 6 shows some details of that test program which now includes over 20 tests of $1000 \mathrm{hr}$, or greater, duration on $\mathrm{CO}_{2}, \mathrm{CH}_{4}, \mathrm{H}_{2}, \mathrm{NH}_{3}, \mathrm{~N}_{2}, \mathrm{H}_{2} \mathrm{O}$ (steam), and $\mathrm{N}_{2} \mathrm{H}_{4}$. Sample temperatures were held at $1400{ }^{\circ} \mathrm{C}$ except for methane and hydrazine for which lower temperatures were used, respectively, to avoid decomposition and simulate the output of a hydrazine catalyst bed. The calculated lifetimes, based on a criterion of a 10 percent mass loss and an assumption of linear mass loss with time, were generally over $1 \times 10^{5} \mathrm{hr}(\mathrm{F} 1 \mathrm{~g} .6)$. These lifetimes are far greater than required for the space Station application. Further life verification tests included the recent completion 23 of a $2000 \mathrm{hr} / 2400$ thermal cycle test of a laboratory model platinum resistojet operated on $\mathrm{CO}_{2}$. This test confirmed many of the processes planned for the flight thruster, such as diffusion bonding and welding, and provided information on phenomena such as grain growth as a function of temperature and materials treatment.

The potential impacts of plumes were of high interest to various potential users of the Space station. A program was, therefore, initiated 24 to characterize the upstream and downstream plumes of the multipropellant resistojet. Accurate determination of low level flow fields, especially upstream of the nozzle, is an extremely difficult process and was found to require very high pumping speed vacuum chambers, using large amounts of cryogens, and special test equipment, such as precision temperature controlled quartz crystal microbalances. The plume characterization effort is still in progress but initial results (Fig. 7) are promising in that reasonable agreement has been obtained between measurements and simple plume predictions 24 of the downstream plume shapes.

Several engineering mode 3,15 resistojets have been fabricated and tests are underway to characterize the performance, thermal properties, and 
electrical interfaces as a function of propellant type and power level. The Space Station power distribution is now planned to be about $208 \mathrm{~V}$ at $20 \mathrm{kHz}$. Gruber 25 has designed and integrated a power processor concept which provides electrical isolation and $20 \mathrm{kHz}$ to the thruster. The power processor is extremely simple, consisting of less than ten parts, and limits inrush currents in order to minimize thermal/mechanical shocks on startup.

\section{High Performance Resistojets}

Efforts are underway to increase the specific impulse of low power, hydrazine resistojets from the $300 \mathrm{sec}$ level, presently avallable, 2 to $335 \mathrm{sec}$ and greater. Analytical and experimental studies of fundamental phenomena, of special importance at low Reynolds number conditions, are in progress, along with efforts to design and verify the performance and lifetimes of high specific impulse resistojets.

The Reynolds numbers of resistojet, and arcjet, nozzles are very low, typically less than 2000 to 3000 . As a consequence, boundary layers are thick and the flow flelds will be very different from potential flow situations. Calculations have been intiated 26 of the nozzle flows and an example, for a Reynolds number and expansion ratio of $10^{3}$ and $10^{2}$, respectively, is shown in Fig. 8. The thick boundary layers are evident and, as has been typically found, the Mach number peaks near the throat region. As much of the flow is subsonic, ambient vacuum facility conditions can potentially affect observed performance. Tests to determine ground test effects are underway. 27 The thrust levels of a single resistojet, operated at various flow rates of heated and unheated nitrogen, were directly measured and the usual thrust correction to account for ambient pressure was then applied. The corrected specific impulses of unheated flows were unaffected by the facllity pressure over the range evaluated. With heated flows, however, there was a consistent increase of corrected specific impulse, up to 7 percent, as the pressure was reduced to less than about $5 \mu \mathrm{m}$. At present, it is felt that the observed behavior is due to heat transfer effects and work is continuing to establish general criteria for correction of thrust measurements for very low pressure operation.

Experimental evaluations of low Reynolds number nozzles are also in progress. 28 Unheated hydrogen and nitrogen are being tested with bell, conical, and trumpet shaped nozzles over ranges of expansion ratios, divergence angles, and Reynolds numbers from 25 to $200,15^{\circ}$ to $25^{\circ}$, and 500 to 6000 , respectively. In general, little variation of nozzle efficiency with nozzle design was observed at Reynolds numbers above about 1500 . Although preliminary, at lower Reynolds numbers the trumpet and conical nozzles appear to show better performance than the bell nozzles, with the difference increasing with decreasing Reynolds numbers.

Component tests for high temperature resistojets are underway and a design with potential for a mission average specific impulse above $335 \mathrm{sec}$ has been completed by the Rocket Research Company. 29 The concept will use: (1) a pressurized heater cavity to reduce sublimation, (2) rhenium for improved creep rupture, and (3) high temperature stable surface texturing to increase heat transfer efficlency over the life of the resistojet. At present, plans are to test a precursor design in mid 1987 to validate design concepts prior to fabrication and tests of a flight type thruster in late 1987 .

\section{Low Power DC Arcjets}

The NASA arcjet program has concentrated to date on low power $D C$ arcjets which are candidates for auxiliary propulsion. It should be noted that the Air Force sponsored arcjet program has concentrated on high power, approximately $30 \mathrm{~kW}, D C$ arcjets.30-32 A strong interaction in arcjet technology is maintained between the Air Force and NASA via a Memorandum of Agreement (MOA) between the Air Force Rocket Propulsion Laboratory and the NASA Lewis Research Center. This interaction fosters rapid interchange of information, which is of importance due to the generic applicability of many findings of the Air Force and NASA arcjet programs.

In initial tests with state-of-the-art, low power arcjets, 33 startup was very erratic and was of ten accompanied by significant cathode and anode erosion. Typically, startup would be accompanied by sparking during arc ignition and very unstable volt-ampere arc characteristics subsequent to arc ignition. The flow fields in the heat exchanger were changed to include a strong vortex. Additionally, a power processor which used pulsed startup and very rapid response circuits was designed and implemented. 34 These two changes, along with minor geometric variations, resulted in reliable, nondamaging arcjet startups (Fig. 9). Subsequentiy, over 300 starts were demonstrated on a $1 \mathrm{~kW}$ arc jet. 35,36 The conditions of the electrodes were evaluated periodically during the startup test program and it was observed that both the cathode shape and the electrical startup characteristics became constant after a few starts and did not significantly change for the duration of the testing. It was also found that the flow fleld and power processor changes led to decreased cathode erosion during steady state operation (Fig. 10).

Arcjet performance tests were performed with hydrazine and hydrogen/nitrogen mixtures over a wide range of flow rates, power levels, and geometries. It was found that the specific impulse was nearly specified by the ratio of power to mass flow rate for many thruster geometries (Fig. 11) and values of specific impulse between 400 and $730 \mathrm{sec}$ were demonstrated with hydrazine propellant. 37 An attractive feature of arcjet systems is their potential for use of space qualified subsystems. This commonality was verified by the successful integration of an arcjet with the catalyst bed, propellant management components, and mounting structure used with operational resistojets. ${ }^{9}$

Arcjets used for $\mathrm{N}-\mathrm{S}$ stationkeeping will be required to operate between about 200 and $300 \mathrm{hr}$. Life tests of $100 \mathrm{hr}$ on hydrogen-nitrogen gas mixtures and $40 \mathrm{hr}$ on hydrazine have been performed on laboratory, $1 \mathrm{~kW}$ class arcjets. 38 After an initial burn in period, wherein the cathode assumed an equilibrium shape, the thruster run on gas mixture performed with negligible change in arc characteristics. The hydrazine arcjet exhibited an increasing arc voltage during the tests. Efforts are underway to determine the cause of the performance 
variation observed during the hydrazine life test and preliminary indications are that it was due to the design used, as opposed to any special effects of hydrazine.

\section{High Power Thrusters}

Research was performed on puised and microwave electrothermal thrusters. Interest in these devices arises from their special characteristics which promise high performance and long lifetimes at very high levels of power. The Pulsed Electrothermal Thruster (PET) alone, of present electric propulsiun concepts, operates at pressures $(200$ to $1000 \mathrm{~atm}$ ) high enough to allow recovery of molecular inelastic energy losses. This feature offers the promise of uniquely high efficiencies at specific impulses from 1000 to $1500 \mathrm{sec}$. Strong progress was made in PET research by the demonstration 39 of operation on water at an average power level of 500 to $600 \mathrm{~W}$. Efficlencies in excess of 0.5 were achieved at a specific impulse of $1400 \mathrm{sec}$ and indications were that efficiencies as high as 0.75 might be achieved through operation at higher power and in lower pressure facilities.

Research has continued on the microwave electrothermal thruster. ${ }^{40}$ This concept offers promise in that it has been demonstrated that microwave energy can be very efficiently transferred to a gas. Additionally, plasmas can be suspended away from direct contact with electrodes. These two features may allow very high power densities to be maintained consistent with wall temperatures appropriate for long life. Microwave energy coupling efficiencies up to 0.98 have been achieved with nitrogen and helium at powers up to $2 \mathrm{~kW}$ and plasma temperatures and densities have been directly measured. Additionally, a number of interesting spinoff applications of microwave plasma heating have been identified, including atomic oxygen sources and material processing.

\section{Ion}

Efforts in ion propulsion included work on thruster R\&T, auxillary propulsion developments, and system technologies.

\section{Thruster R\&T}

Strong advances were made in the performance modeling of multipole ion thrusters. Brophy and wilbur, in a series of publications, 41-44 have provided both theoretical analyses and experimental results to validate and illuminate their models. A single algebraic equation was developed 41 to predict the beam ion energy cost as a function of propellant utilization in terms of four parameters essentially specified by the thruster geometry and propellant type and the two controllable operating parameters: propellant flow rate and discharge voltage. For discharge voltages above propellant dependent values, this model correctly predicted 42 observed variations in beam ion energy production costs as a function of propellant type, ion beam extraction area, discharge voltage, transparency of ion optics to neutral propellant, and discharge chamber wall temperature. 43 The basic performance mode 147 was then extended 44 in order to allow prediction of primary electron densities and Maxwellian electron densities and temperatures. Experiments performed with argon and xenon propellants were in good agreement 44 with the predicted plasma properties. These efforts are important in that the general impacts of variations in multipole thruster geometries and operating points can now be estimated with a fidelity not previously avallable.

Due to the major benefits of high power thrusters for high power systems 18 efforts continue to extend the operating envelopes of both divergent field and multipole inert gas thrusters. Xenon, $30-\mathrm{cm}$ thrusters have been operated 45 for several hundred hours at $10 \mathrm{~kW}$ and components, such as cathodes, ${ }^{45}$ capable of operating at significantly increased emission currents, have been demonstrated (F1g. 12). Designs of $50-\mathrm{cm}$ thrusters have been completed and the tooling required to fabricate appropriate ion optics, the highest risk element in $50-\mathrm{cm}$ thruster demonstration, has been completed and blanks of stainless steel and molybdenum successfully dished.

\section{Auxiliary Propulsion Developments}

Both 8-cm Ion Auxiliary Propulsion System (IAPS) mercury ion thruster systems were removed from the DOD spacecraft, successfully test fired, and reinstalled on the spacecraft. The space test now awalts a flight opportunity on the space shuttle orbiter.

Efforts to determine the wear mechanisms of the INTELSAT/Hughes Research Laboratories (HRL), $25-\mathrm{cm}$, xenon ion thruster 46 are nearing completion. In a test co-sponsored by INTEI.SAT, HRL, and NASA, the ion thruster has accumulated over $4400 \mathrm{hr}$ and 3700 cycles at nominal power and thrust levels of $1.3 \mathrm{~kW}$ and $65 \mathrm{mN}$, respectively. Electrical power and propellant are supplied by the simplified power processor and flight type pressure regulator described in Ref. 46. The hours and cycles already achieved are well in excess of those required for 10 years of $N$.S stationkeeping, by a single thruster, of an INTELSAT VI class spacecraft.

\section{Systems Technology}

Work is underway at JPL to address issues which are important to ion propulsion systems and to evaluate system considerations which affect subsystem and component technology requirements.

Simpler, more reliable ion systems result from both decreasing the number of thruster/power processor units, by increasing the power per thruster, and operating on xenon propellant. For those reasons, the $2.7 \mathrm{~kW} \mathrm{J-Series} \mathrm{mercury} \mathrm{thruster} \mathrm{was} \mathrm{mod}$ ified to operate at $5 \mathrm{~kW}$ on xenon. Modifications necessary to affect those operating changes included: (1) removal of all insulating materials subject to high temperature degradation including kapton, teflon, and vespel, (2) development of a new, high voltage xenon propellant isolator, (3) use of solid ground screens, and (4) implementation of very compliant ion optics mounting systems. 47 Further system simplification has been accomplished through the use of a central neutralizer subsystem. This system consists of two neutralizer cathodes. Only one neutralizer is used at a time to neutralize the ion beams from both engines. The second cathode is included for redundancy.

To provide reliable on-command engine and neutralizer cathode ignition, a gas pulse starting 
system was developed. This system uses the simultaneous application of $500 \mathrm{v}$ to the keeper electrode and a short duration gas pressure pulse through the cathode to assure transition through the Paschen breakdown criterion. The use of this system also eliminates the need to precondition the cathode insert after exposure to air.

To assure an engine lifetime of $15000 \mathrm{hr}$, techniques by which the internal sputter erosion may be reduced are being investigated. 48 This includes primarily looking at the effect of the addition of small amounts of other gases such as nitrogen to the propellant to inhibit sputtering. Erosion rates are measured by exposing a section of material polished to a mirror finish to the engine discharge chamber plasma for up to $12 \mathrm{hr}$ and then measuring the etch depth with a profilometer.

An ion propulsion module using two, $5 \mathrm{~kW}$, xenon ion thrusters has been developed as a test bed for systems technology 49 and is shown in operation in Fig. 13. A computer contral system was developed to operate the propulsion module autonomously (Fig. 14). The computer control system can simultaneously or sequentially start any combination of the two engines and two neutralizer cathodes. In addition, the capability to throttle an engine under computer control between a beam current of 0.75 and 4.0 A has been demonstrated. During normal operation the computer control algorithms provide proportional control of the discharge current and cathode flow rate to maintain the beam current and discharge voltage set points. The main flow rate is varied along with the cathode flow to maintain the desired propellant utilization efficiency. Any of the set points (beam current, discharge voltage, propellant efficlency and beam voltage) may be changed from the computer keyboard during engine operation. This allows flexibility in throtting the engine that has never been available before. In addition, the engine gimbal system is also under computer control and the gimbal angle may be selected from the keyboard during operation. Finally, the program can be operated in a mode in which it will read preprogrammed commands stored on a magnetic disk. The computer will then execute these commands, such as start-up, throttle, etc., as a function of "mission time."

The implementation of concepts which simplify and increase the reliability of ion systems, along with demonstration of those concepts in multithruster systems with flight type control philosophies, is an important step toward ultimate acceptance of ion systems for major space missions.

\section{Electromagnetic}

In the electromagnetic area, research is underway to provide understanding of the phenomena controliing electromagnetic propulsion, and to explore thruster concepts with potential for operation at very high power levels.

Major advances in plasma thruster theory have recently been made at Princeton University. For the first time, a universal description of pure electromagnetic (MPD) thruster voltage/current terminal behavior has been obtained. 50 The model has been verified over a wide range of thruster propellant types, propellant flow rates, and thruster geometries (Fig. 15).
A characteristic current, $J_{F I}$, at which full ionization occurs in coaxial plasma thrusters, has been defined in terms of first principles. At currents below JFI, the hybrid regime, the plasmas are partially ionized and based on extensive reviews of plasma thruster performance, the ion velocities appear to be limited to Alfvén speeds. At currents above J J , the fully ionized regime, the analyses indicate that thruster efficiencies, based on electromagnetic force contribution only, may be limited to values less than achievable in the hybrid regime. Based on these results, efforts are now underway to explore the performance potentials of thrusters operated in the hybrid regime, which represents the transition operating mode between high pressure electrothermal and fully ionized plasma thrusters.

Experiments also revealed both the highly nonequilibrium nature of coaxial plasma thrusters and the presence of plasma waves which are central to their operation. A generalized criterion for electron superthermalization by the observed plasma waves was identifled and shown to be present in coaxial thrusters. In order to better understand plasma wave phenomena, experiments were implemented which allow direct evaluation of the wave frequencies as a function of wavelength, or wave dispersion relationships (Fig. 16).

Additionally, a steady state coaxial plasma thruster faclity is now operational that allows steady state thruster operation at power levels up to $40 \mathrm{~kW}$ at propellant flow rates up to $8 \times 10^{-3} \mathrm{~kg} / \mathrm{sec}$ and background pressures less than $5 \times 10^{-4}$ torr. These new experimental capabilities will provide insights into the importance of plasma instabilities to thruster behavior and the potential performance and life levels of hybrid plasma thrusters.

Under Air Force sponsorship, Princeton University has developed 52 and refined a nuclear surface layer activation (SLA) measurement for in-situ measurement of MPD thruster component erosion. Recent efforts have improved callbration and data management techniques and resolution of erosion depths of about $0.25 \mu \mathrm{m}$ are now possible. The SLA technique has been established and is an excellent candidate for in-situ erosion rate measurements in many electric propulsion devices in which there are hostile environments, and very low erosion rates.

Efforts are also ongoing 52 at JPL to provide the technology required for multimegawatt MPD thrusters for high energy applications such as cargo vehicles for Earth-orbit transfer and Mars missions. The approach taken has been to define and test a progression of subscale MPD thrusters of increasing power leve1. Testing is now underway with a thruster sized to operate at power and arc current levels up to $100 \mathrm{~kW}$ and $3000 \mathrm{~A}$, respectively (Fig. 17). The thruster has operated for a total of $8.5 \mathrm{hr}$ during 72 tests of up to 55 min duration. The highest power level attained to date was $72 \mathrm{~kW}$ at an arc current of $1700 \mathrm{~A}$. No performance data have been taken as performance. is expected to be poor at these arc current levels which are relatively low for the self field MPD concept. However, the plasma densities and temperatures demonstrated are projected to be similar to those of full scale, megawatt engines.

Lifetime and reliability are key issues in the subscale MPD test program. In that regard, recent 
experimental findings pertaining to: (1) startup procedures, (2) the cathode-insulator interface, and (3) cathode temperatures are presented.

The startup process is found to be critical in that a cold start always entalls erosion of the cathode, and usually the nearby insulator. Once a significant asymmetry in either the cathode or the insulator shape develops, a symmetric, stable arc is almost impossible to obtain. A smooth, nondestructive starting technique has been devised. This employs an auxiliary set of gas injection jets to support a $800 \mathrm{~W}$ glow discharge. This discharge heats the cathode to incandescence at which point the main power may be applied, without any visible erosion.

The cathode-insulator interface is a location of particularly high power density and heat loads in the MPD thruster. Testing has shown that the arc on the cathode tends to burn underneath the insulator causing rapid insulator erosion. An electrically isolated buffer electrode has been found to solve the problem. When placed within a distance estimated to be smaller than the cathode sheath, the buffer electrode effectively prevents arc damage to the insulator.

Finally, cathode tip temperatures have been measured and found to be within a reasonable upper limit ( 1800 to $\left.1900{ }^{\circ} \mathrm{C}\right)$ such that rapid evaporation is not expected. These temperature measurements were taken over current densities that range from 100 to $200 \mathrm{~A} / \mathrm{cm}^{2}$, which are expected in $\mathrm{full}$ sized MPD thrusters.

\section{Summary}

A number of studies have been recently performed which quantify the benefits of electric propulsion for a very broad set of space missions. These analyses additionaliy helped define technologies of highest relevance to future missions. The research and technology programs in electrothermal, ion, and electromagnetic propulsion have resulted in significant technical advancements in fundamental understanding and hardware maturity. These advancements, along with the ongoing successful flight applications, should result in increased confidence and payoff in application of electric propulsion.

\section{References}

1. Bri11, Y., E1sner, A., and 0sborn, L., "The Flight Application of a Pulsed Plasma Microthruster, The NOVA Satellite," AIAA Paper 82-1-956, Nov. 1982.

2. Sackheim, R.L., and Howell, G.W., "Trends in Propulsion Systems for Geosynchronous Satellites," Paper presented at the 14 th International Symposium on Space Technology and Science, May 28-June 1, 1984, Tokyo, Japan.

3. Pugmire, T.K., Cann, G.L., Heckert, B., and Sovey, J.S., "A 10,000 Hour Life Multiprope1lant Engine for Space Station Applications," AIAA Paper 86-1403, June 1986.

4. Jones, Robert E., "High- and Low-Thrust Propulsion Systems for the Space Station," AIAA Paper 87-0398, Jan. 1987.
5. Pioneering the Space Frontier, Report of the National Commission on Space, Bantam Books, New York, 1986.

6. Nored, D., and Bernatowicz, D.T., "Electrical Power System Design for the U.S. Space Station," Advancing Toward Technology Breakout in Energy Conversion, Vol. III, American Chemical Society, Columbus, OH, 1986, pp. 1416-1422.

7. Wiley, R.L., Verga, R.L., Sholtis, J.A. Jr., Walquist, E.J., and Schnyer, A.D., "Space Reactor Power 1986: A Year of Choices and Transition," Advancing Toward Technology Breakout in Energy Conversion, Vol. III, American Chemical Society, Columbus, OH, 1986, pp. 1411-1415.

8. Kuriki, K., Kawashima, N., Sasaki, S., Yanagisawa, M., and Obayashi, T., "Space Experiment with Particle Accelerators (SEPAC) Performed in Spacelab First," AIAA Paper 85-1996, Sept. 1985.

9. Kitamura, S., Nagano, H., Nakamura, Y., Kudo, I., and Machida, K., "ETS Ion Engine Flight Operations in the Extended Mission Period," AIAA Paper 85-2010, Sept. 1985.

10. Berry, W., "Status Report on the ESA Sponsored Electric Propulsion Developments," AIAA Paper 85-1997, Sept. 1985.

11. Power, J.L., Ignaczak, L.R., Collett, C.R., and Bever, D.R., "Ion Auxiliary Propulsion System (IAPS) 8-cm Mercury Ion Thruster Flight TestStatus and Supporting Ground Tests," AIAA Paper $85-2025$, oct. 1985

12. Schreib, Rolland, "Utility of Xenon Ion Stationkeeping," AIAA Paper 86-1849, June 1986.

13. Graetch, Joseph E., and Unterberg, Walter "Fluid Independence of the Space Station," AIAA Paper 86-2309, Sept. 1986.

14. Tacina, R., Personal Communication, NASA Lewis Research Center, Cleveland, $\mathrm{OH}$, July 1986.

15. Heckert, B.J., "Space Station Resistojet System Requirements and Interface Definition Study," RI/RD87-109, Rockwell International Corp. Canoga Park, CA, Feb. 1987. (NASA CR-179581).

16. Palaszewsk1, Bryan, "Free-Flyer Advanced Propulsion," JPL D-3257, May 1986. (See also Palaszewski, B.A., "Advanced Propulsion for Polar-Orbiting and Co-Orbiting Free Flyers," AIAA Paper 86-1564, June 1986.)

17. Sercel, J., and Krauthamer, S., "Multimegawatt Nuclear Electric Propulsion: First Order System Design and Performance Evaluation," AIAA Paper 86-1202, June 1986.

18. Hardy, T.L., Rawlin, V.K., and Patterson, M.J., "Electric Propulsion Options for the SP-100 Reference Mission." NASA TM-88918, 1987.

19. Mahoney, S.P., and Mekaru, M.M., "Nuclear Powered Ion Engine Orbit Transfer Vehicle Design and Operationa1 Effectiveness," AIAA Paper 86-1391, June 1986 . 
20. Garrison, P.W., and sigurdson, K.B., "LO $\mathrm{L}_{2} / \mathrm{LH}_{2}$ Propulsion for Outer Planet Orbiter Spacecraft," AIAA Paper 83-1305, June 1983.

21. Whalen, M.V., Grisnik, S.P., and Sovey, J.S., "Compatibility Experiments of Facilities, Materials, and Propellants for Electrothermal Thrusters," 1985 JANNAF Propulsion Meeting, Vo 1. 1, Edited by K.L. Strange, CPIA-PUBL-425, Chemical Propulsion Information Agency, Laurel, Maryland, 1985, pp. 475-484.

22. Morren, W.E., Whalen, M.V., and Sovey, J.S., "Performance and Endurance Tests of a Multipropellant Resistojet for Space Station Auxiliary Propulsion," AIAA Paper 86-1435, June 1986.

23. Morren, W.E., and Sovey, J.S., "2000-Hour Endurance Test of a Laboratory Mode 1 Multipropellant Resistojet," AIAA Paper 87-0993, May 1987.

24. Zana, L.M., Hoffman, D.J., Beryley, L.R., and Serafini, J.S., "An Analytical and Experimental Investigation of Resistojet Plumes, "AIAA Paper 87-0399, Jan. 1987.

25. Gruber, R.P., "Resistojet Control and Power for High Frequency ac Buses," AIAA Paper 87-0994, May 1987.

26. Anderson, B., Private Communication, NASA Lewis Research Center, Cleveland, $\mathrm{OH}$, June 1986.

27. Penko, P.F., Manze1la, D.H., Dewitt, K.J., and Keith, T.G., "Effect of Ambient Pressure on the Performance of a Resistojet," AIAA Paper 87-0991, May 1987.

28. Whalen, M.V., Private Communication, NASA Lewis Research Center, Cleveland, $\mathrm{OH}, \mathrm{Feb} .1987$.

29. Smith, W.W., Private Communication, Rocket Research Company, Feb. 1987

30. Pivirotto, T.J., King, D.Q., and Deininger, W.D., "Long Duration Test of a $30-\mathrm{kW}$ Class Thermal Arcjet Engine," AIAA Paper 87-1083, May 1987.

31. Cassaday, R.J., Britt, E.J., and Meya, R.D., "Performance Testing of a Lightweight $30 \mathrm{~kW}$ Arcjet Power Conditioning Unit," AIAA Paper 87-1085, May 1987.

32. Masser, P.S., and Kilgore, 0., "Arcjet Analys is and Modeling," AIAA Paper 87-1089, May 1987.

33. Ducat1, A.C., Humpal, H., Meltzer, J., Muehlberger, E., Todd, J.P., and Waltzer, H., "1-kW Arcjet-Engine System-Performance Test," Journal of Spacecraft and Rockets, Vol. 1, No. 3, May-June 1964, pp. 327-332.

34. Gruber, R.P., "Power Electronics for a 1-Kilowatt Arcjet Thruster," AIAA Paper 86-1507, June 1986.

35. Curran, F.M., and Haag, T.W., "Arcjet Component Conditions Through a Multistart Test," AIAA Paper 87-1060, May 1987.
36. Haag, T.W., and Curran, F.M., "Arcjet Starting Reliability: A Multistart Test on Hydrogen/ Nitrogen Mixtures," AIAA Paper 87-1061, May 1987.

37. Knowles, S.C., Smith, W.W., Curran, F.M., and Haag, T.W., "Performance Characterization of a Low Power Hydrazine Arcjet," AIAA Paper 87-1057, May 1987.

38. Simon, M.A., Knowles, S.C., Curran, F.M., and Hardy, T.L., "Low Power Arcjet Life Issues," AIAA Paper 87-1059, May 1987.

39. Burton, R.L., Fleisher, D., Goldstein, S.A., Tidman, D.A., and Winsor, N.K., "Investigation of a Repetitive Pulsed Electrothermal Thruster," GTD86-5, GT-Devices, Alexandria, VA, Aug. 1986. (NASA CR-179464).

40. Hawley, M.C., Asmussen, J., Filpus, J.W., Whitehair, S., and Chapman, R., "A Review of Research and Development on the Microwave-Plasma Electrotherma 1 Rocket," AIAA Paper 87-1011, May 1987.

41. Brophy, J.R., and Wilbur, P.J., "Simple Performance Model for Ring and Line Cusp Ion Thrusters," AIAA Journal, Vol. 23, No. 11, Nov. 1985, pp. 1731-1736.

42. Brophy, J.R., and Wilbur, P.J., "An Experimental Investigation of Cusped Magnetic Field Discharge Chambers," AIAA Journal, Vol. 24, No. 1, Jan. 1986, pp. 27-26.

43. Wilbur, P.J., and Brophy, J.R., "The Effect of Discharge Chamber Wall Temperature on Ion Thruster Performance," AIAA Journal, Vol. 24, No. 2, Feb. 1986, pp. 278-283.

44. Brophy, J.R., and Wilbur, P.J., "Calculation of Plasma Properties in Ion Sources," AIAA Journal. vol. 24, No. 9, Sept. 1986, pp. 1519-1523.

45. Rawlin, V.K., Private Communication, NASA Lewis Research Center, Cleveland, OH, Feb. 1987.

46. Beattie, J.R., Matossian, J.N., Poeschel, R.L., Rogers, W. and Martinelli, R., "Xenon Ion Propulstion System," AIAA Paper 85-2012, Sept. 1985.

47. Aston, G., and Brophy, J.R., "Ion Accelerator System Mounting Design and Operating Characteristics for a $5 \mathrm{~kW} 30-\mathrm{cm}$ Xenon Ion Engine," AIAA Paper 87-1075. May 1987.

48. Garner, C.E., Brophy, J.R., and Biasca, R.J., "The Effects of Gas Mixtures on Ion Engine Erosion and Performance," AIAA Paper 87-1080, May 1987.

49. Aston, G., Brophy, J.R., Garner, C.E., and Pless, L.C., "Operating Characteristics of a 10 kW Xenon Ion Propulsion Module," AIAA Paper 87-1006, May 1987.

50. Choueiri, E.Y., Kelly, A.J., and Jahn, R.G., "Instabilities in the MPD Thruster Plasma," AIAA Paper 87-1067, May 1987. 
51. Polk, J.E., Kelly, A.J., and Jahn, R.G., "MPD Thruster Erosion Research," AIAA Paper 87-0999, May 1987.
52. King, D.Q., "Design and Operation of a $100 \mathrm{~kW}$, Subscale MPD Englne," AIAA Paper 87-1020, May 1987.

TABLE 1. - NET MASS AND COST BENEFITS PROVIDED BY XENON ION PROPULSION ${ }^{\mathrm{a}}$

\begin{tabular}{|c|c|c|c|c|}
\hline \multirow[t]{3}{*}{ Power source } & \multicolumn{4}{|c|}{ Spacecraft stabilization technique } \\
\hline & \multicolumn{2}{|c|}{ Spin } & \multicolumn{2}{|c|}{ Three axis } \\
\hline & $\begin{array}{l}\text { Batteries } \\
\text { and solar }\end{array}$ & $\begin{array}{l}\text { Batteries } \\
\text { and solar }\end{array}$ & $\begin{array}{l}\text { Solar } \\
\text { only }\end{array}$ & $\begin{array}{l}\text { Batteries } \\
\text { and solar }\end{array}$ \\
\hline Thrust, $\mathrm{mN}$ & 35 & 130 & 130 & 130 \\
\hline $\begin{array}{l}\text { Net mass } \\
\text { benefit, } \mathrm{kg}\end{array}$ & 303 & 218 & 216 & 260 \\
\hline $\begin{array}{l}\text { New cost } \\
\text { benefit, } \$ M\end{array}$ & 64 & 44 & 41 & 54 \\
\hline
\end{tabular}

anef. 12.

TABLE 2. - CO-ORBITING FREE FLYER SERVICING PROPELLANT REQUIREMENTS, $K G^{a}$

\begin{tabular}{|c|c|c|c|c|}
\hline \multirow[t]{2}{*}{ Mission } & \multicolumn{4}{|c|}{ Propulsion technology } \\
\hline & $\begin{array}{l}\text { Hydrazine } \\
\text { chemical }\end{array}$ & Resistojet & Arcjet & Ion \\
\hline $\begin{array}{l}\text { Hubble telescope } \\
\text { AXAF }\end{array}$ & $\begin{array}{r}1681 \\
682\end{array}$ & $\begin{array}{r}1239 \\
523\end{array}$ & $\begin{array}{l}614 \\
257\end{array}$ & $\begin{array}{r}108 \\
45\end{array}$ \\
\hline $\begin{array}{l}\text { Micro-gravity, } \\
\text { variable-gravity }\end{array}$ & 52 & 39 & 19 & 4 \\
\hline $\begin{array}{l}\text { Gamma ray } \\
\text { observatory }\end{array}$ & 3704 & 2894 & 1475 & 264 \\
\hline
\end{tabular}

a Ref. 16.

TABLE 3. - COST OF DEPLOYMENT OF GPS GALAXY (28 SATELLITES)

\begin{tabular}{|l|c|}
\hline Propulsion system & $\begin{array}{c}\text { Deployment cost, } \\
\$ M\end{array}$ \\
\hline Reusable NEPSa & 538 \\
PAM D-II & 822 \\
Centaur-G & 2491 \\
IUS & 3848 \\
\hline
\end{tabular}

a70 day delivery time. 


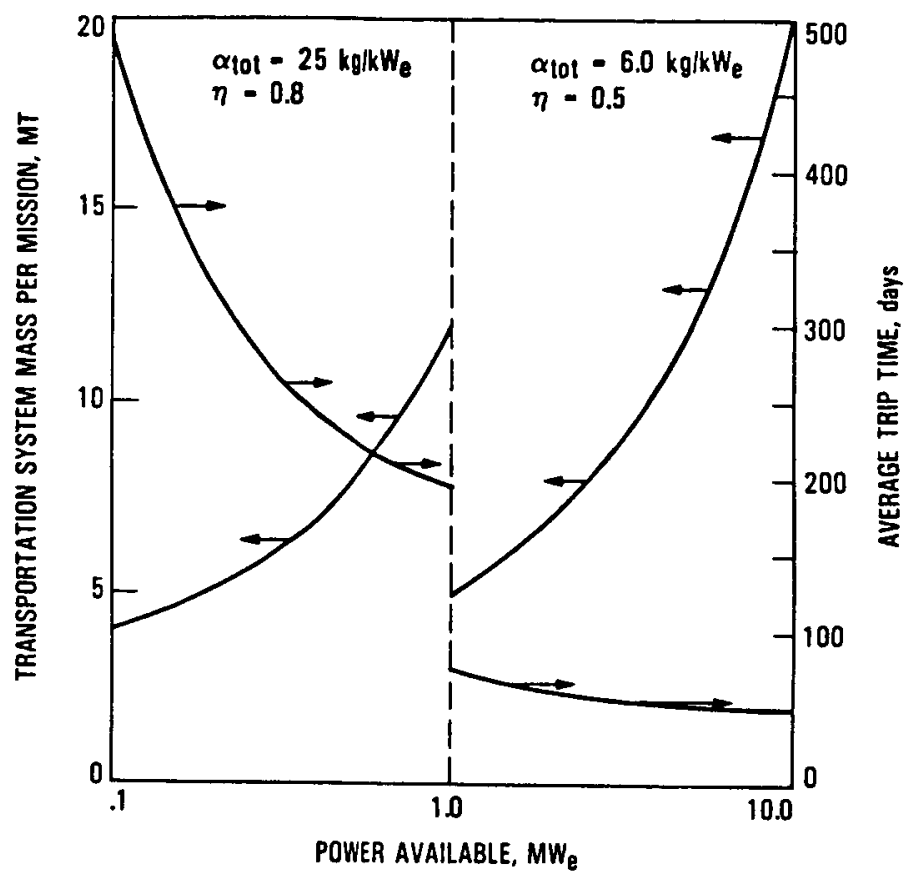

(A) LEO TO GEO.

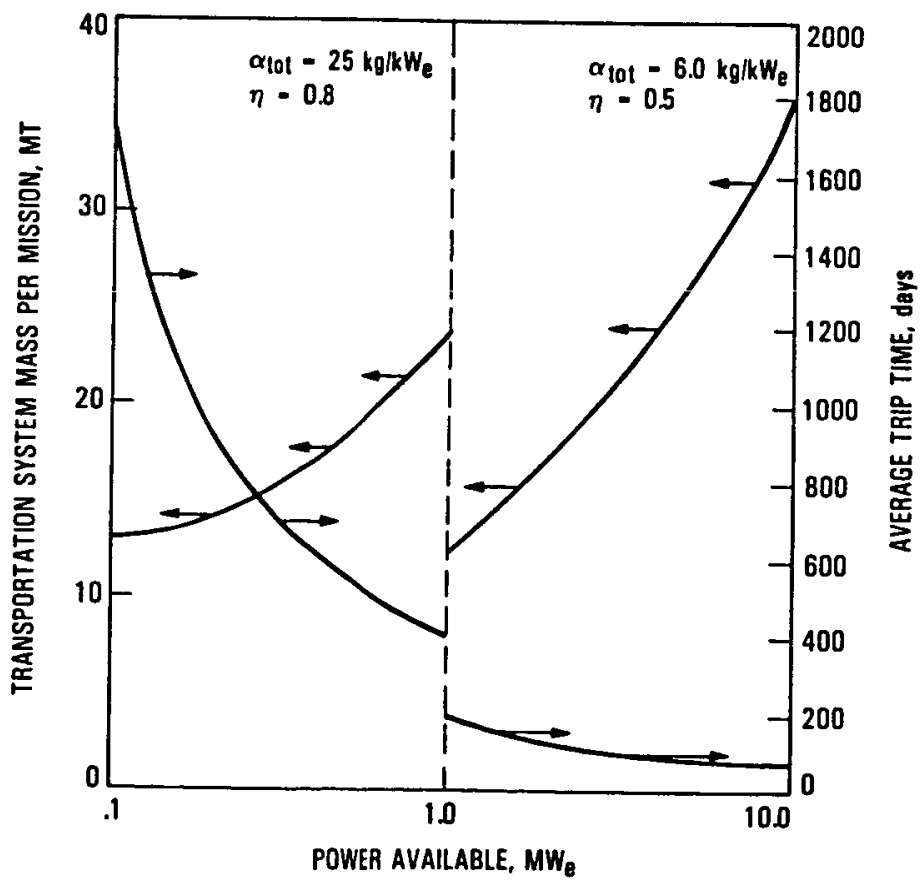

(B) LUNAR BASE.

FIGURE 1. - NEPS MASSES AND TRIP TIMES. (17) 


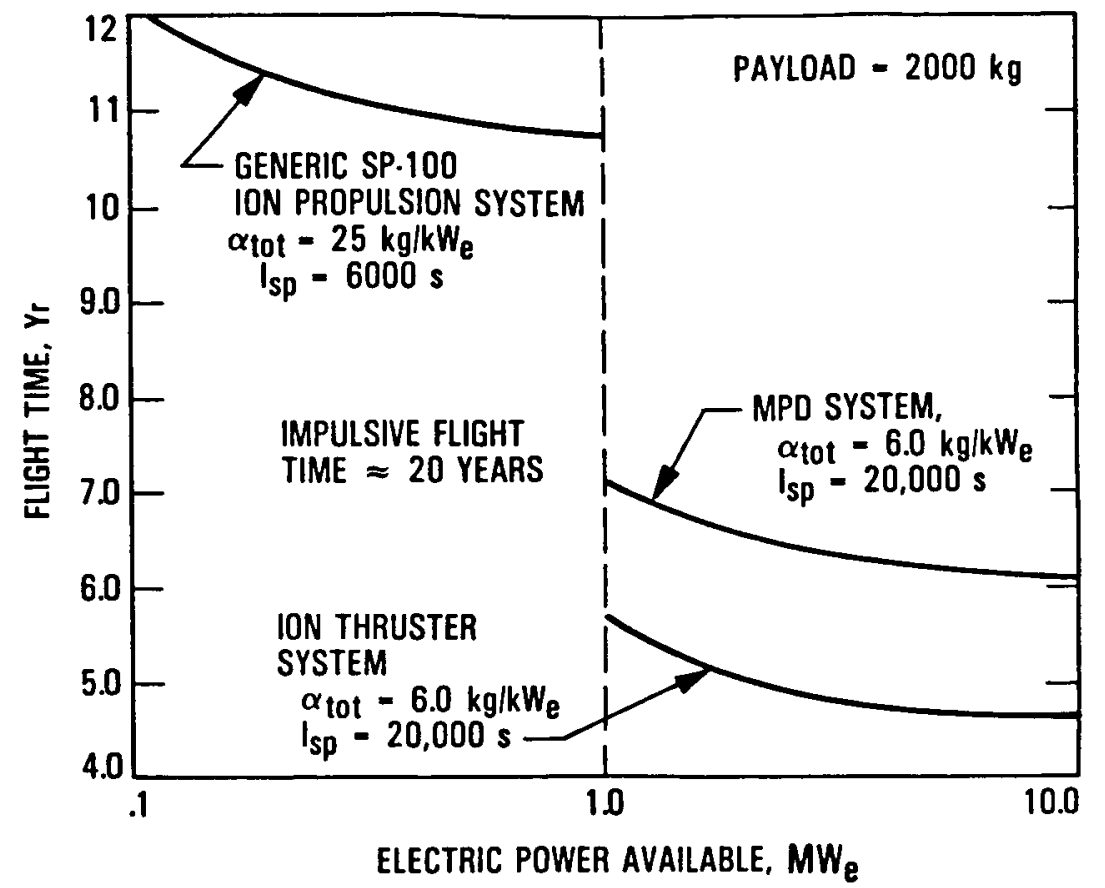

FIGURE 2. - NEPTUNE ORBITER FLIGHT TIMES VERSUS NEPS POWER LEVEL. (17)

$300 \mathrm{~kW}$ SP-100 REFERENCE MISSION STS MASS DISTRIBUTIONS

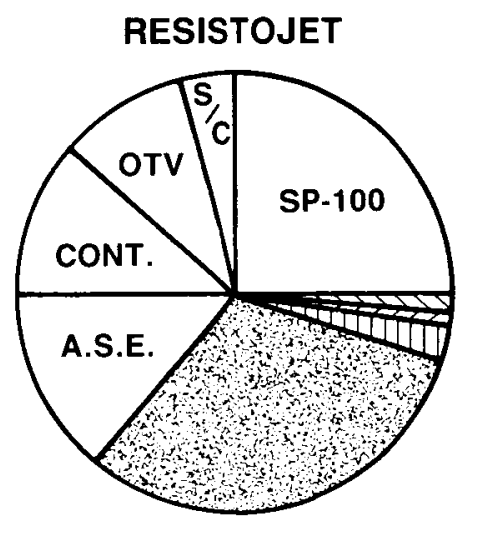

- PROPULSION SYSTEM DRY MASS IS A SMALL FRACTION OF THE STS PAYLOAD
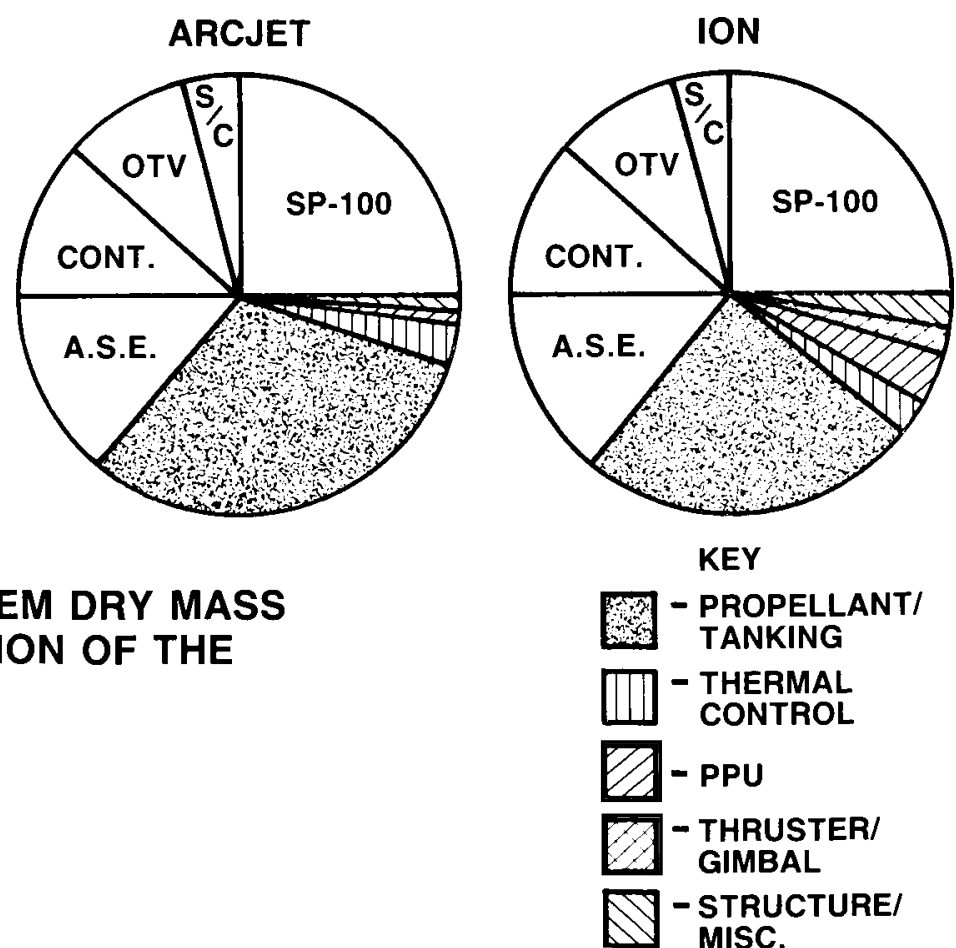

FIGURE 3. - MASS DISTRIBUTIONS FOR SP-100 REFERENCE MISSION AT $300 \mathrm{~kW}{ }^{(18)}$ 


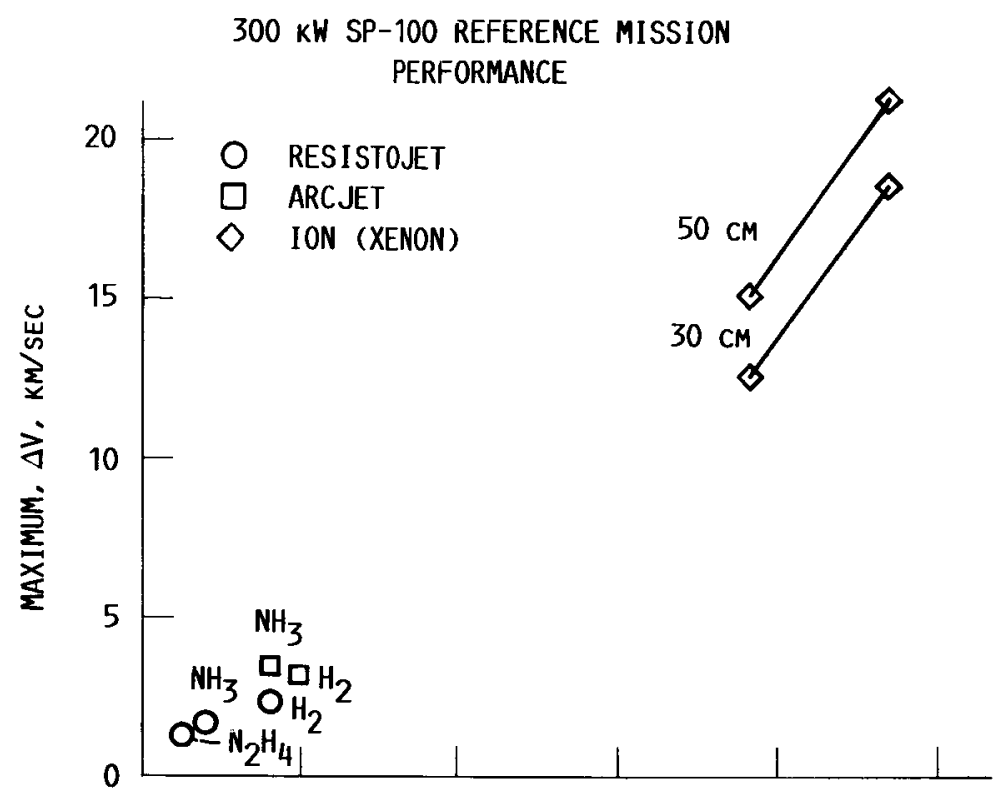

(A) MAXIMUM VELOCITY INCREMENT.

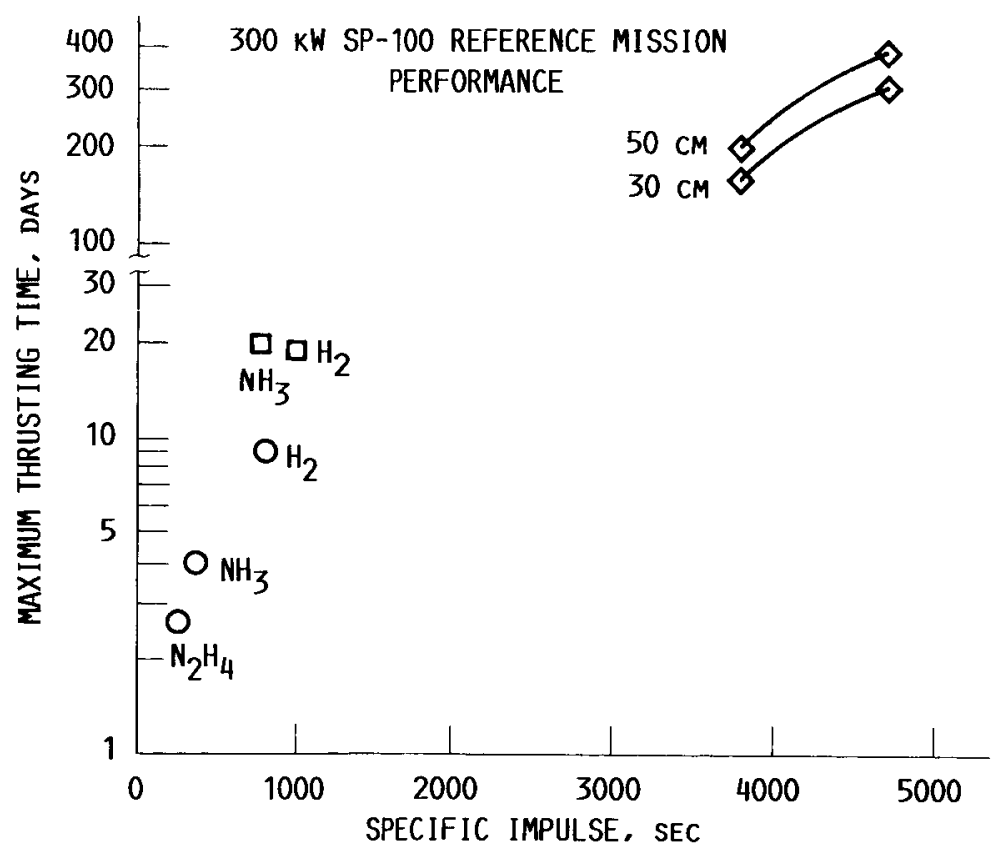

(B) MAXIMUM THRUSTING TIME.

FIGURE 4. - MISSION PERFORMANCES OF $300 \mathrm{~kW}$ ELECTRIC PROPULSION SYSTEMS FOR SP-100. ${ }^{(18)}$ 


\title{
SPACE STATION DRAG MAKEUP USING RESISTOJETS
}

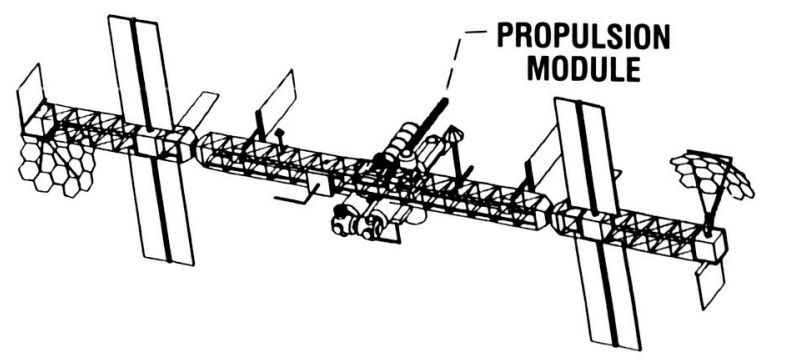

\author{
EARLY SPACE STATION
}
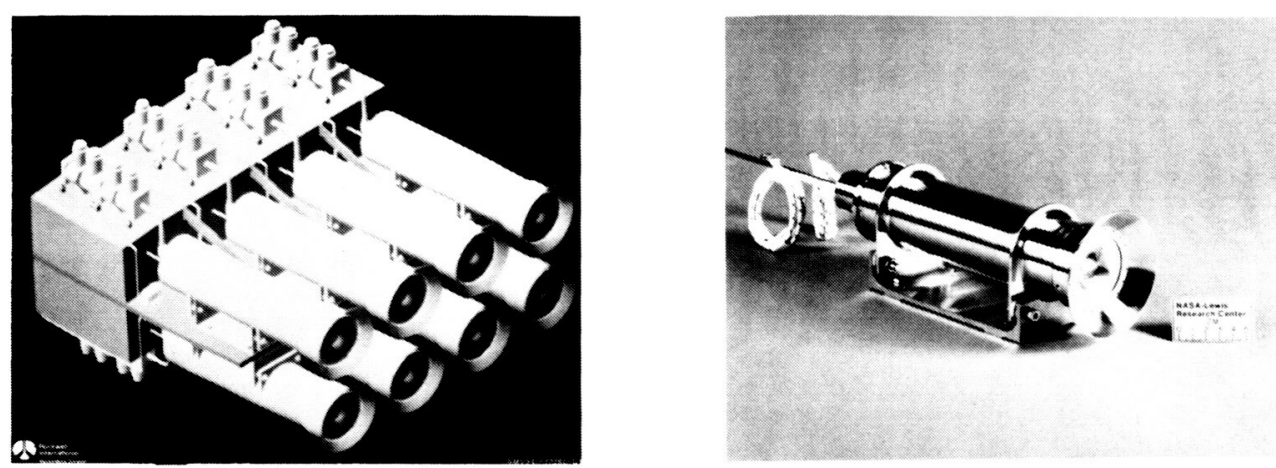

RESISTOJET PROPULSION MODULE

FIgURE 5. - RESISTOJET DRAG MAKEUP MODULE AND THRUSTER. ${ }^{(4)}$

\section{SPACE STATION RESISTOJET COMPATIBILITY EXPERIMENTS}

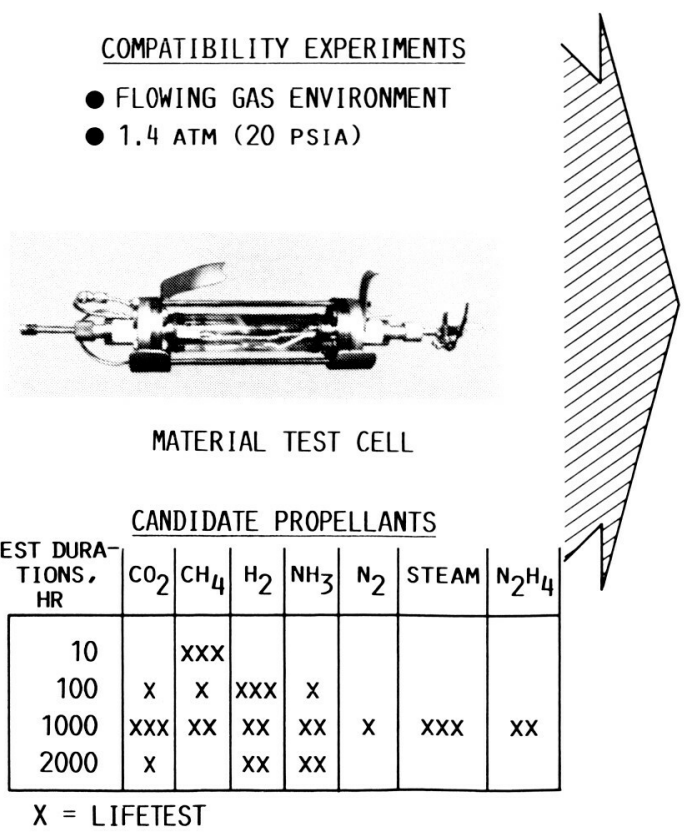

\begin{tabular}{|c|c|c|}
\hline GAS & $\begin{array}{l}\text { HEATER TEM- } \\
\text { PERATURE, } \\
\text { OC }\end{array}$ & $\begin{array}{c}\text { GRAIN STABILIZED } \\
\text { PLAT INUM LIFE。 } \\
\text { K-HR }\end{array}$ \\
\hline $\mathrm{CO}_{2}$ & 1400 & 300 \\
\hline $\mathrm{CH}_{4}$ & 500 & 1500 \\
\hline $\mathrm{H}_{2}$ & 1400 & 200 \\
\hline $\mathrm{N}_{2}$ & 1400 & 106 \\
\hline $\mathrm{N}_{2} \mathrm{H}_{4}$ & 800 & 980 \\
\hline STEAM & 1400 & 110 \\
\hline
\end{tabular}

- LIFETIMES EXTRAPOLATED LINEARLY FROM 1000 HOUR TEST RESULTS

- 10\% MASS FAILURE CRITERION

FIGURE 6. - RESISTOJET COMPATIBILITY TEST APPROACHES AND RESULTS. (21) 
ORIGHAL PAGE IS

OF POOR NIIAIITY

\section{PLUME RESEARCH}

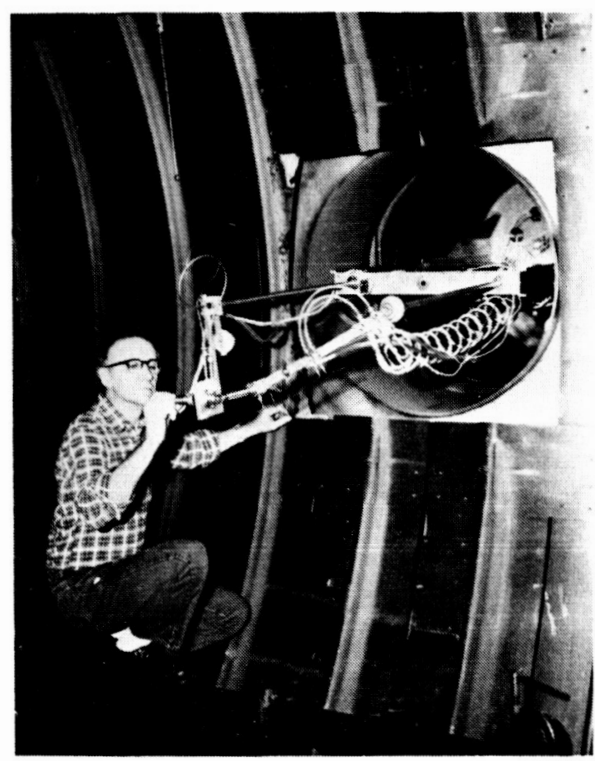

COMPARISON OF QCM WITH SIMON'S METHOD

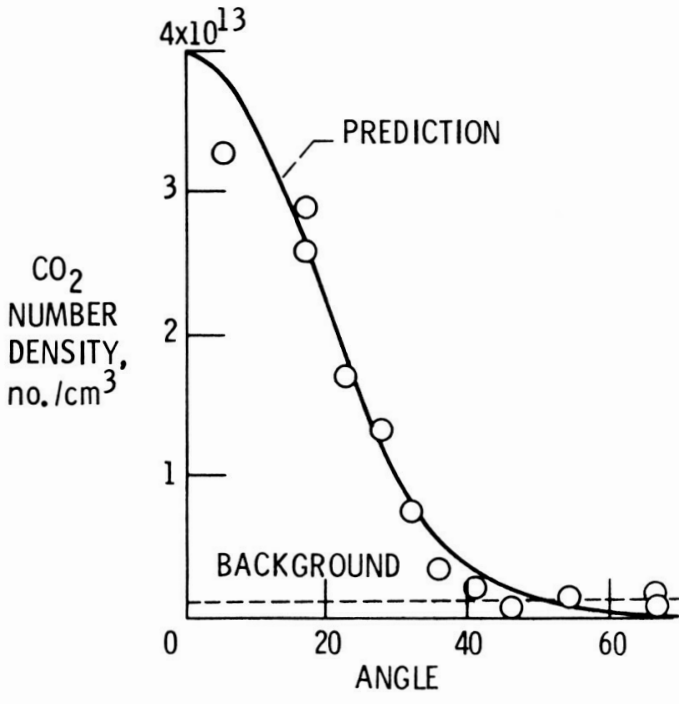

CD-86-19746

FigURE 7. - RESISTOJET PLUME CHARACTERIZATIONS. (24)

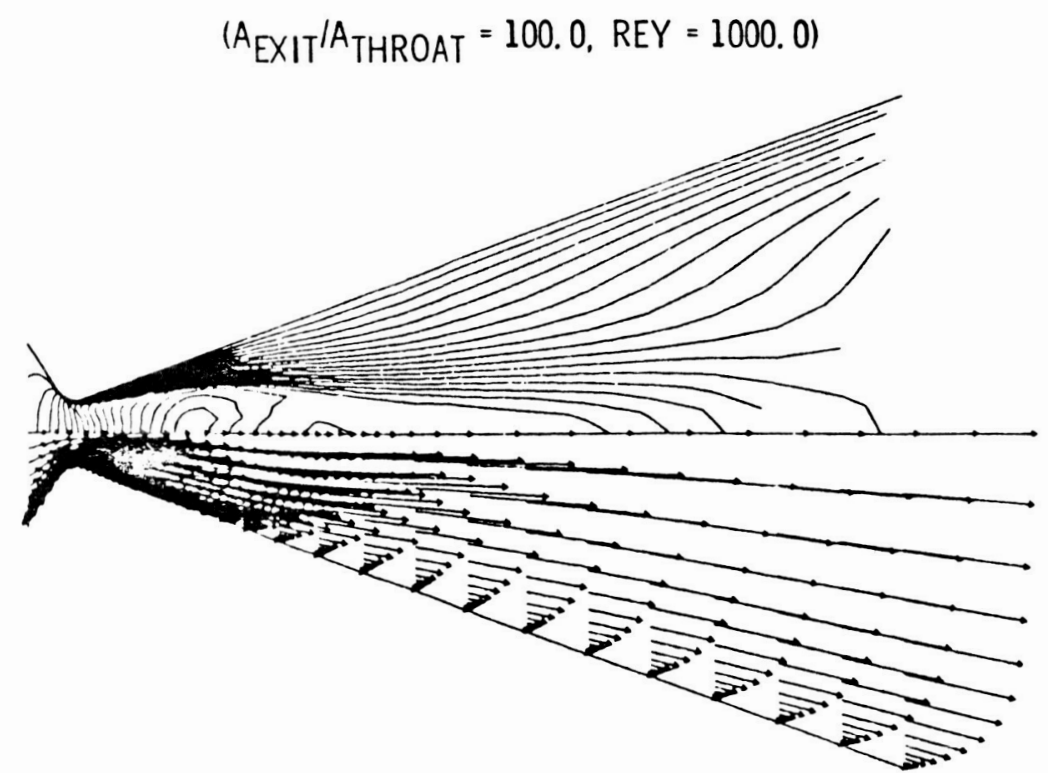

FIGURE 8. - MACH NUMBER AND STREAMLINE VELOCITY VECTORS. 


\section{RELIABLE, NON - DAMAGING ARCJET STARTING}

- START - UP DAMAGE ELIMINATED VIA OPTIMIZATION:

- FLOW FIELDS - POWER CIRCUITS

- GEOMETRY

NON - OPTIMIZED
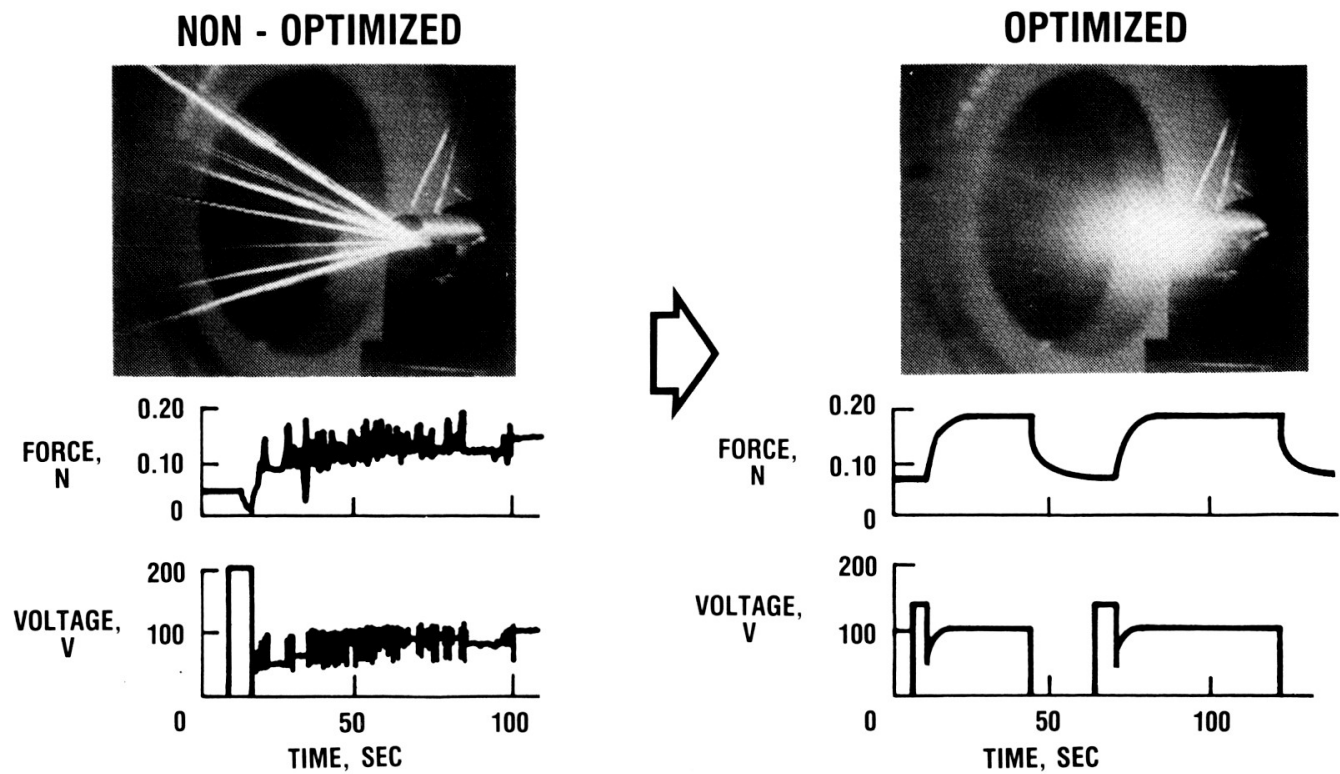

OPTIMIZED

- RELIABLE START-UP ENABLES LONG-LIFE MULTI-START OPERATION

FiguRE 9. - ARCJET STARTING PHENOMENA. (35)

\section{CATHODE MATERIALS TESTING}

- THORIATED TUNGSTEN CATHODES

- NEARLY IDENTICAL OPERATING CONDITIONS

- INCREASING VORTEX STRENGTH DECREASES CATHODE DAMAGE

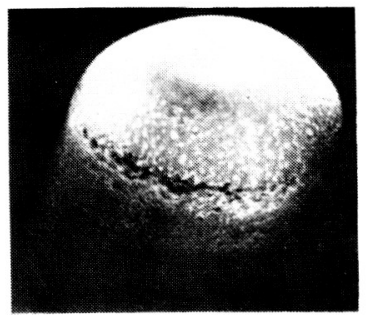

- $30 \mathrm{X}$

- $8 \mathrm{Hrs}$

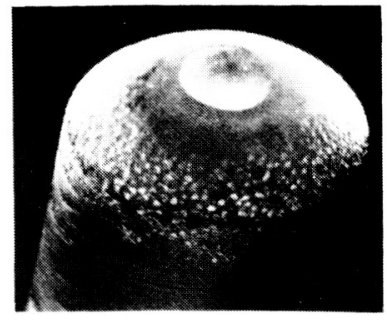

- $30 \mathrm{X}$

- 8 Hrs

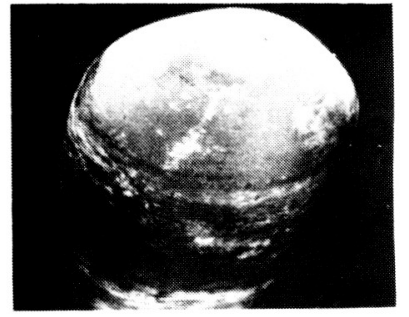

- 30X

- $6.5 \mathrm{Hrs}$

$$
S=0.063
$$

$S=0.072$

$S=0.089$

Figure 10. - CATHODE DAMAGE as a Function OF VORTEX StRENGth. (36) 
- IsP APPROXIMATELY SPECIFIED BY P/m OVER RANGE OF GEOMETRIES TESTED

- ISP VALUES FROM 400 TO 730 SECONDS ACHIEVED ON HYDRAZINE

- NO FUNDAMENTAL LIMIT OBSERVED; HIGHER SPECIFIC IMPULSE VALUES POSSIBLE
SPECIFIC IMPULSE VERSUS POWER/MASS FLOW RATE

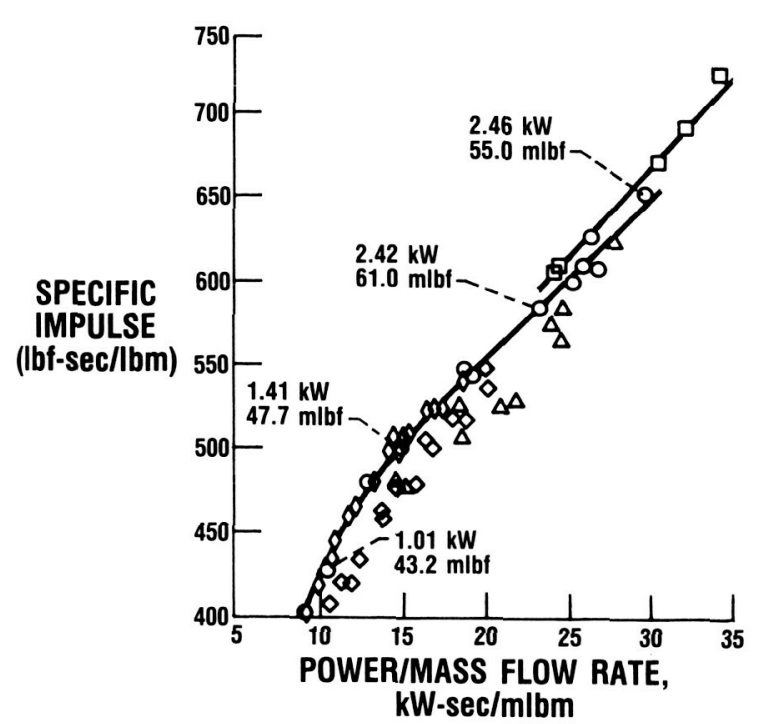

FIGURE 11. - HYDRAZINE ARCJET PERFORMANCE VERSUS POWER TO MASS FLOW RATIO. (37)

\section{LOW TEMPERATURE, HIGH CURRENT HOLLOW CATHODE}

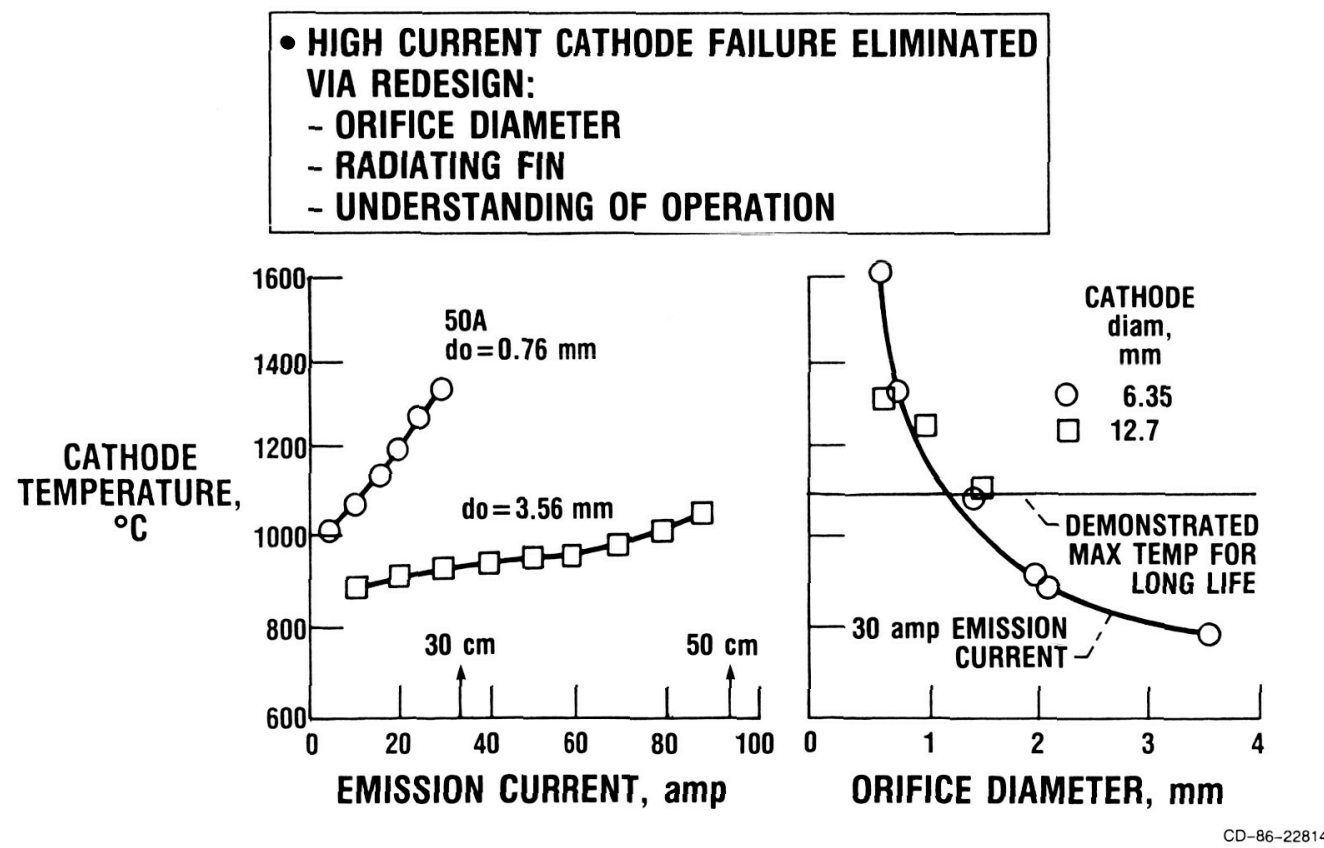

FIGURE 12. - HOLLOW CATHODE TEMPERATURE VERSUS CURRENT AND ORIFICE DIAMETER. (45) 


\section{ORIONAL PACE IS \\ OF POOR QUALITY}

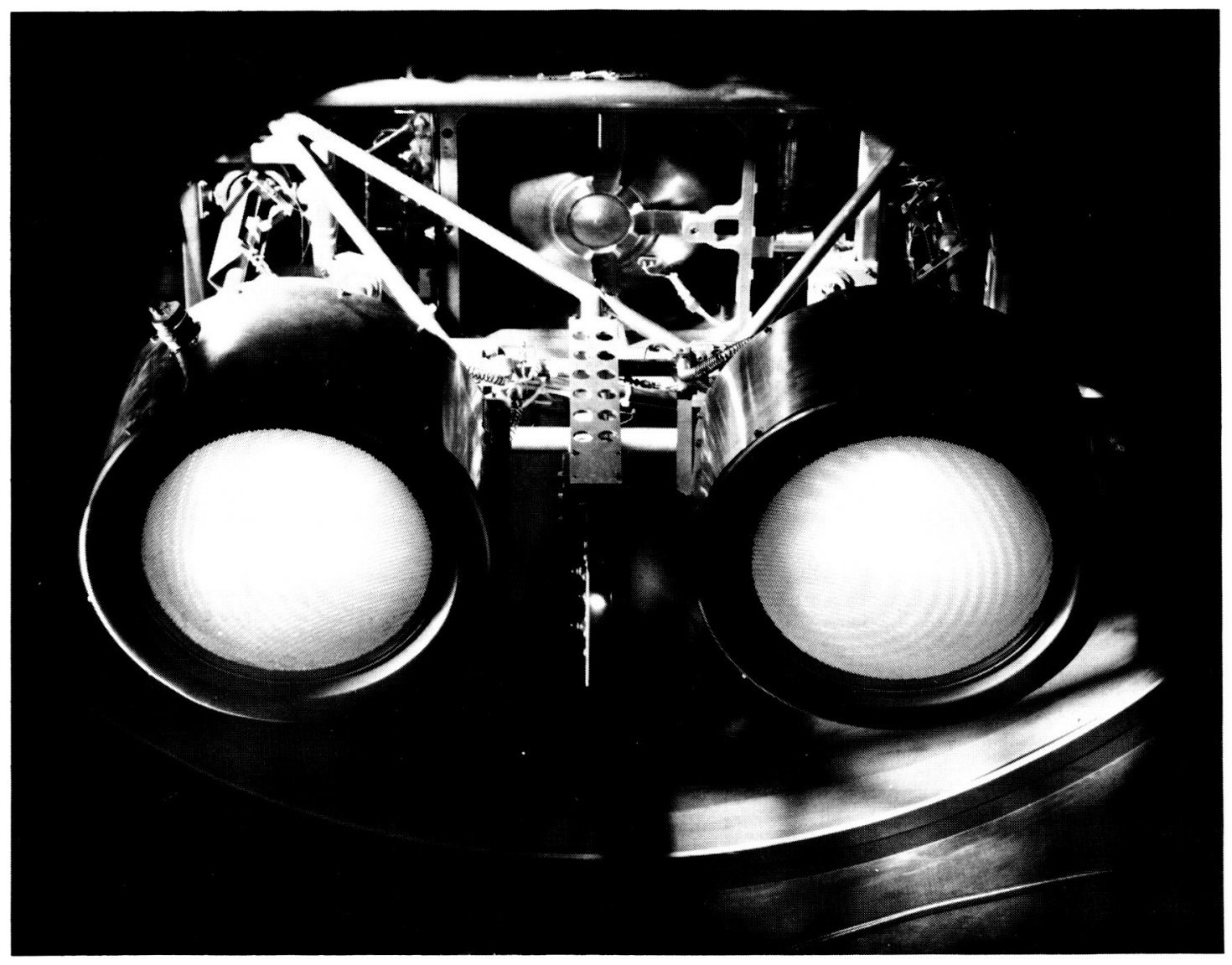

FIGURE 13. - $10 \mathrm{~kW}$ XENON ION PROPULSION MODULE. (49) 


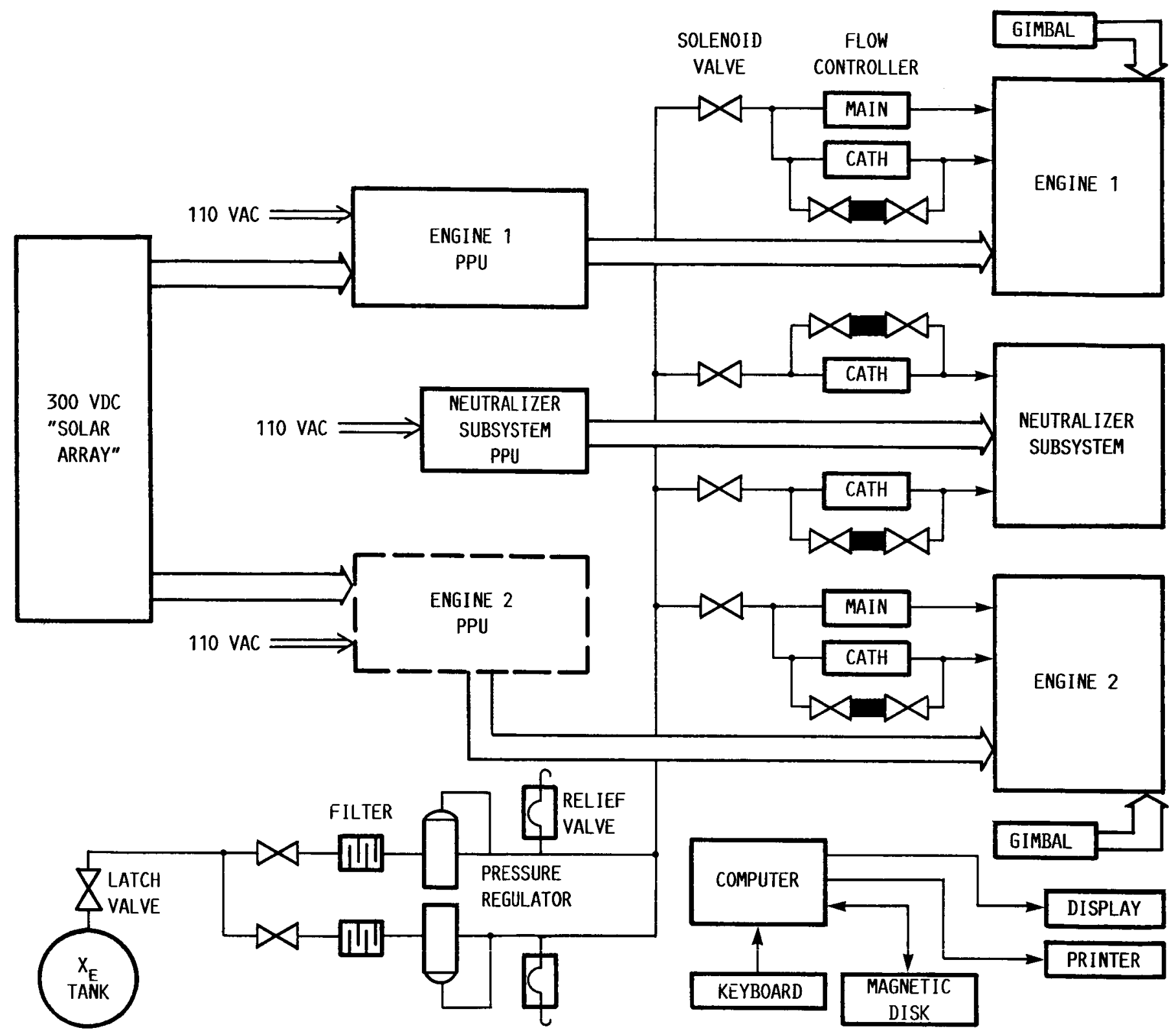

FIGURE 14. - $10 \mathrm{~kW}$ XENON ION PROPULSION MODULE CONTROL SYSTEM. ${ }^{(49)}$ 


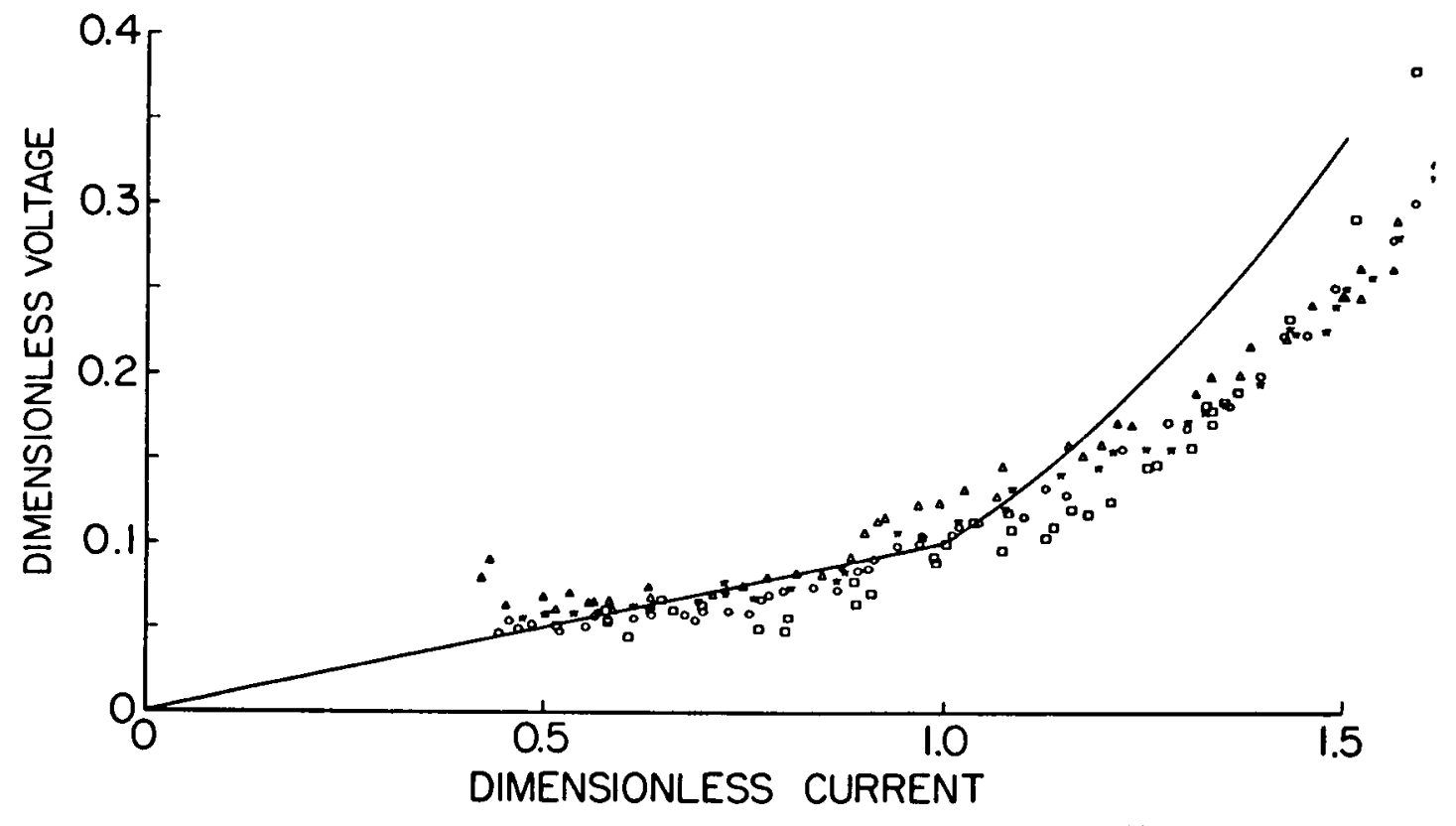

FIGURE 15. - COMPARISON OF MPD ARC MODEL WITH DATA. ${ }^{(50)}$

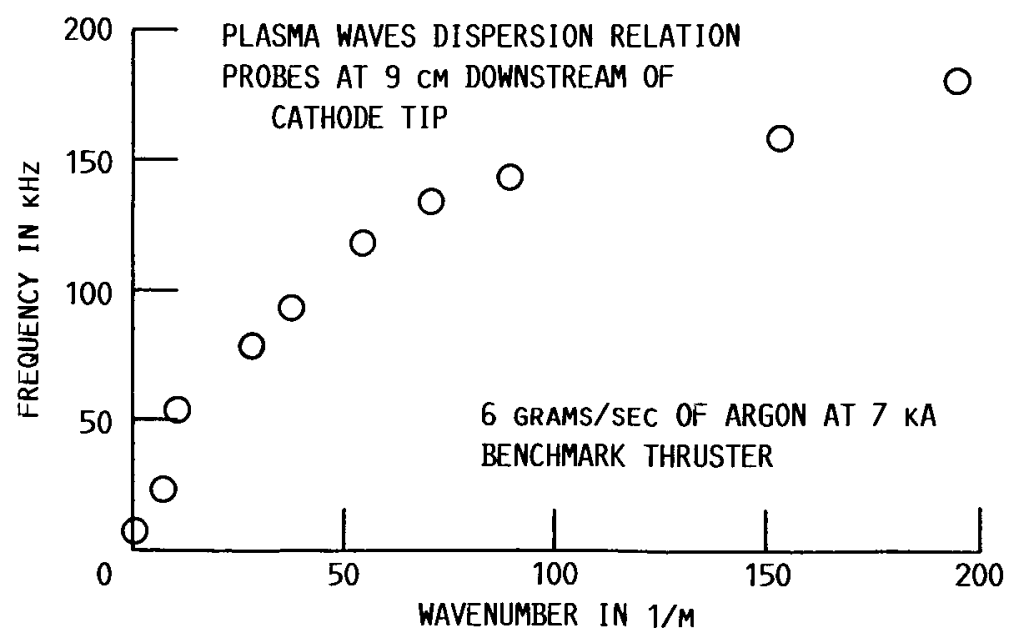

FIGURE 16. - PLASMA WAVE DISPERSION RELATIONSHIP WITH BENCHMARK MPD, ${ }^{(50)}$ 
ORGMA PACE IS

OF POCR NIIAITY

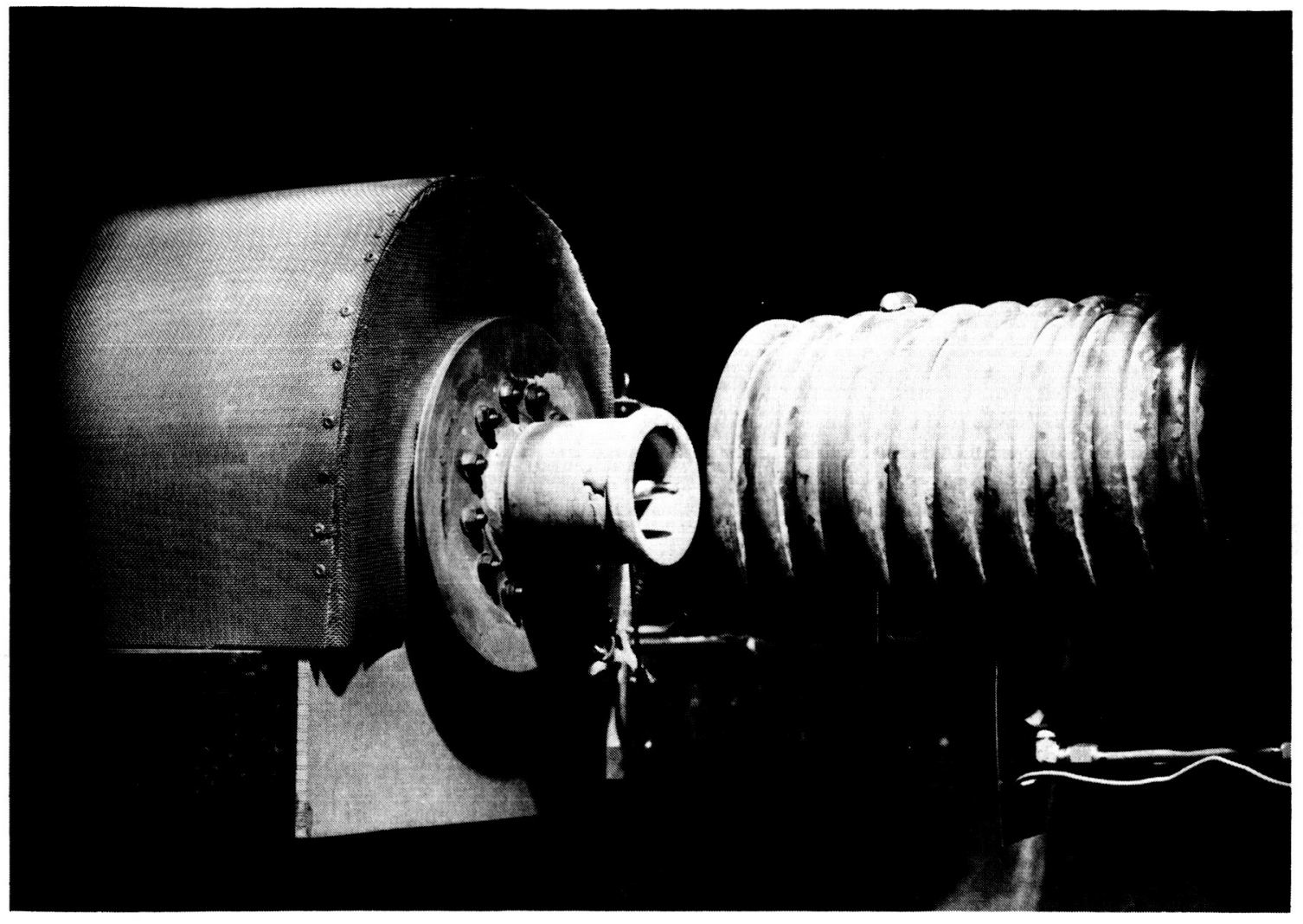

FIGURE 17. - $100 \mathrm{~kW}$ SUBSCALE MPD THRUSTER. 


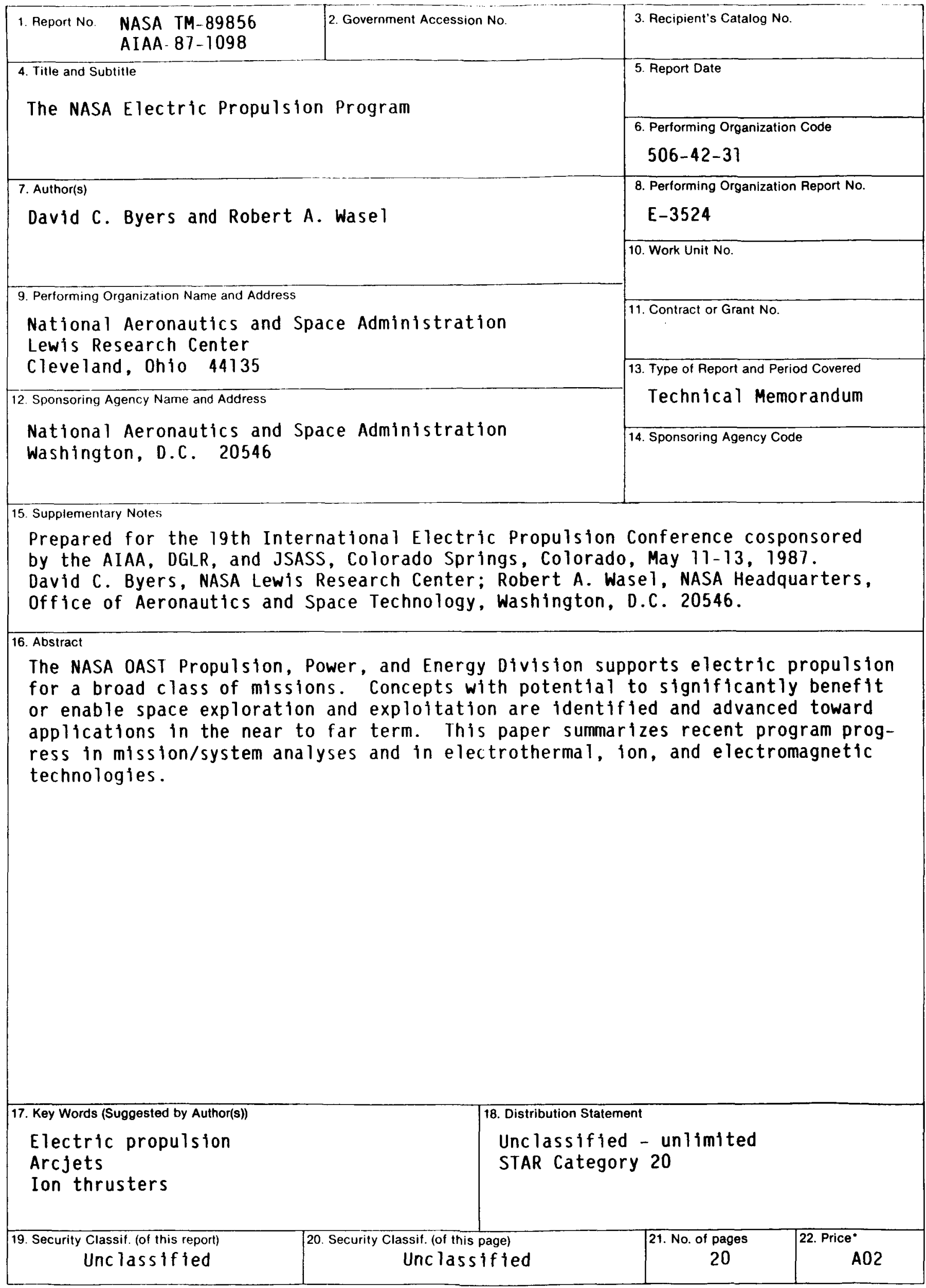

"For sale by the National Technical Information Service, Springfield, Virginia 22161 